\title{
Melamine, Asam Sianurat dan Melamin-Sianurat: Kaitan dengan Penyakit Saluran Perkencingan Hewan
}

\author{
Melamine, Cyanuric Acid and Melamine-Cyanurate: the Link to the \\ Diseases of Urinary Tract in Animal
}

\author{
Yanuartono", Alfarisa Nururrozi, Soedarmanto Indarjulianto, Harry Purnamaningsih, Slamet Rahardjo \\ Departemen Ilmu Penyakit Dalam, Fakultas Kedokteran Hewan, Universitas Gadjah Mada \\ Jl. Fauna 2, Karangmalang, Yogyakarta 55281 Indonesia \\ *Email: yanuartono@ugm.ac.id
}

Naskah diterima: 7 Agustus 2019, direvisi: 3 September 2019, disetujui: 23 Oktober 2019

\begin{abstract}
High incidence of acute renal failure in dogs and cats from 2004-2007 were associated with the ingestion of dog and cat food products and the suspected contaminant was identified as melamine and its derivatives such as cyanuric acid and melamine cyanurate. Melamine is a chemical compound used primarily in the plastics manufacture, coatings, commercial filters, adhesives also main component of dinnerware and kitchen appliances industry. However, melamine has been misued to elevate the content of nitrogen compounds in human and animal food. Increasing the content of nitrogen compound by using melamine aim to increase the value of protein in food. Melamine has broad safety limit thus relatively non-toxic if consumed by human and animal. However, many studies and case reports showed that melamine can cause damage to the kidneys, especially if present together with cyanuric acid in the body. This paper aims to provide an overview and discussion of urinary tract obstruction in dogs and cats that is likely caused by toxicity of melamine and its derivatives which possibly occuring in Indonesia.
\end{abstract}

Key words: cyanuric acid; food products; melamine cyanurate acute renal failure; toxicity

\begin{abstract}
Abstrak
Sejumlah kasus gagal ginjal akut pada anjing dan kucing sejak 2004-2007 dikaitkan dengan konsumsi produk pakan anjing dan kucing yang dicurigai telah terkontaminasi oleh melamin dan senyawa turunannya seperti asam sianurat dan melamin sianurat. Melamin adalah bahan kimia yang digunakan terutama untuk pembuatan plastik, pelapis, filter komersial, perekat dan senyawa dalam industri pembuatan piring serta alat dapur. Namun kemudian senyawa ini telah disalahgunakan untuk meningkatkan kandungan senyawa nitrogen dalam produk makanan pada manusia dan pakan pada hewan. Peningkatan kandungan senyawa nitrogen dari melamin tersebut bertujuan untuk meningkatkan nilai protein bahan pangan maupun pakan. Melamin pada dasarnya memiliki batas keamanan yang lebar sehingga relatif tidak beracun jika terkonsumsi manusia dan hewan. Namun demikian, banyak penelitian dan laporan kasus yang menunjukkan bahwa melamin dapat mengakibatkan kerusakan pada ginjal terutama jika bereaksi dengan asam sianurat di dalam tubuh. Makalah ini bertujuan untuk memberikan gambaran dan diskusi mengenai kasus kerusakan saluran kemih pada anjing dan kucing disebabkan oleh keracunan melamin dan turunannya yang kemungkinan sudah terjadi di Indonesia.
\end{abstract}

Kata kunci: asam sianurat; gagal ginjal akut; melamin; melamin sianurat; produk pakan 


\section{Pendahuluan}

Melamin dan turunannya seperti asam sianurat dan melamin sianurat adalah komponen yang diduga kuat mengakibatkan wabah besar gagal ginjal pada anjing dan kucing yang terjadi pada tahun tahun 2007 di Amerika Utara (Puschner et al., 2007). Laporan di Asia menyebutkan bahwa pada tahun 2004 telah terjadi wabah gagal ginjal pada anjing, yang menunjukkan gejala klinis, histologis, dan toksikologi yang identik dengan kejadian di Amerika Utara pada tahun 2007. Kejadian gagal ginjal akut pada hewan piaraan di Asia selama bulan Maret 2004 menunjukkan adanya kemungkinan disebabkan karena produk pakan yang diproduksi di salah satu pabrik di Thailand (Brown et al., 2007). Kejadian tersebut diatas mengakibatkan ditariknya secara besar besaran produk produk pakan hewan kesayangan seperti anjing dan kucing dari pasaran (FDA, 2008).

Kerusakan pada ginjal juga telah dilaporkan pada tahun 2008 di China dimana banyak anakyang menderita dan bahkan meninggal karena kerusakan ginjal setelah mengonsumsi susu yang terkontaminasi melamin (Reimschuessel et al., 2010; Ji et al., 2014). Selain makanan bayi, melamin pun ditemukan susu, produk asal susu serta produk makanan dan pakan lainnya, yang juga diekspor ke banyak negara di seluruh dunia (Gossner et al., 2009). Kejadian kontaminasi makanan oleh melamin juga telah dilaporkan di Selandia Baru, Taiwan, Korea Selatan, Kongo. Kontaminasi makanan oleh melamin di Eropa dilaporkan terjadi di Austria, Finlandia, Jerman, Slowakia, dan Hungaria (Suchý et al., 2009). Penyebab masalah tersebut akhirnya diketahui berasal dari komponen bahan pakan mengandung melamin yang ditemukan dalam gluten gandum, jagung, dan protein beras diimpor dari China, dengan tujuan meningkatkan nilai protein (Liu et al., 2011). Latar belakang penambahan secara illegal tersebut disebabkan karena mahalnya bahan pangan maupun pakan yang mengandung protein tinggi yang sayangnya berdampak negatif pada manusia maupun hewan yang mengkonsumsinya. Kecurangan tersebut didukung lemahnya uji kandungan protein yang terdapat dalam bahan pangan maupun bahan pakan. Sampai saat ini uji kadar protein nonspesifik ditentukan melalui pengukuran nitrogen dengan metode uji standar seperti Kjeldahl (Montesano et al., 2013). Menurut Cheng et al., (2010), meskipun toksisitas oral melamin dinyatakan rendah namun dapat mengakibatkan kerusakan pada ginjal jika bereaksi dengan asam sianurat di dalam tubuh. Toksisitas rendah melamin kemungkinan menjadi penyebab tidak banyak data di lapangan yang diperoleh pada kucing (Puschner et al., 2007). Tulisan ini bertujuan untuk memberikan gambaran dan bahasan secara sederhana pada kasus kerusakan saluran perkencingan pada anjing dan kucing yang kemungkinan disebabkan oleh toksisitas melamin, asam sianurat, dan melamin sianurat yang kemungkinan terjadi di Indonesia. Dugaan tersebut didasarkan atas banyaknya kasus kasus gangguan saluran perkencingan pada kucing yang ditemukan di Klinik Hewan Kuningan, FKH-UGM (Nururrozi et al., 2018). Selain tujuan tersebut diatas, penulis juga berharap bahwa nantinya akan muncul penelitian pada komponen bahan-bahan yang terdapat dalam produk pakan anjing dan kucing yang kemungkinan terkait dengan kejadian gangguan saluran perkencingan.

\section{Struktur dan Sifat Kimia}

\section{Melamin}

Melamin dengan rumus formula kimia $\mathrm{C} \mathrm{H} \mathrm{N}$ dan nama IUPAC 1,3,5-triazine-2,4,6- triamine $\left(^{3} \mathrm{Gam}^{6}{ }^{6}\right.$ bar 1) adalah triazina heterosiklik kaya nitrogen (Liu et al., 2012). Melamin memiliki nama lain sianuramida, sianurotriamida, sianurotriamina, isomelamin, triaminotriazin, 2,4,6-triaminotriazin, triamino-striazin, 2,4,6-triamino-1,3,5-triazine, 2,4,6-s-triazinetriamin, dan 1,3,5-triazina-2,4,6 $(1 \mathrm{H}, 3 \mathrm{H}, 5 \mathrm{H})$-triimina (International Agency for Research on Cancer, 2010). Senyawa kimia ini berbentuk kristal putih padat, mempunyai sifat sedikit larut dalam air $(3,1 \mathrm{~g} / 1$ pada suhu $20^{\circ} \mathrm{C}$ ), sedikit larut dalam etanol, dan tidak larut dalam dietil eter (Anonim, 2009).

Melamin bisa diproduksi dari tiga bahan yang berbeda seperti urea, dicyandiamide atau hidrogen sianida (Maxwell, 2007). Pada awal 1940 Mackay menemukan bahwa melamin juga bisa disintesa dari urea pada suhu $400^{\circ} \mathrm{C}$ dengan atau tanpa katalis. Sejak saat itu melamin mulai diproduksi dari bahan

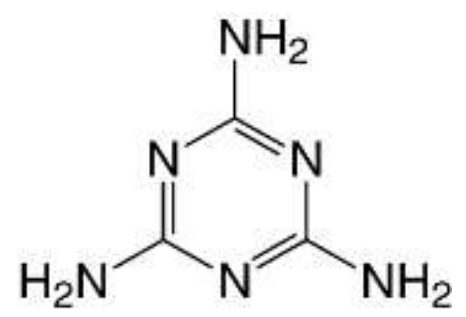

Gambar 1. Struktur kimia melamin (Bizzari and Yokose, 2008) 
baku urea dan penggunaan cyanamid sebagai bahan baku dihentikan pada akhir 1960 (Ingelfinger, 2008). Melamin digunakan dalam sintesis melamin- resin formaldehid (MFR) untuk pembuatan plastik (Sugita et al., 1990), pelapis (Park and Jeong, 2010), filter komersial, perekat (Kumar and Katiyar, 1990), dan senyawa dalam industri pembuatan piring serta alat dapur (Liu et al., 2012).

\section{Asam sianurat}

Asam sianurat dengan rumus formula kimia $\mathrm{C}_{3} \mathrm{H}_{3} \mathrm{~N}_{3} \mathrm{O}_{3}$ atau $\mathrm{C}_{3} \mathrm{~N}_{3}(\mathrm{OH})_{3}$ (gambar 2) dan nama IUPAC 1,3,5-triazinane-2,4,6-trione adalah oksitriasin analog melamin sebagai produk sampingan dalam sintesis melamin dan berbentuk kristal putih. Asam sianurat dapat digunakan untuk sintesis disinfektan, klorinasi air kolam renang (Downes et al., 1984), antioksidan (She et al., 2010), pelapis cat (Whitten and Lin, 1999), herbisida (Huthmacher and Most, 2005), plastik, polyester dan kosmetik (Chuenarrom et al., 2014) serta feed additive ruminansia (Barboza and Barrionuevo, 2007).

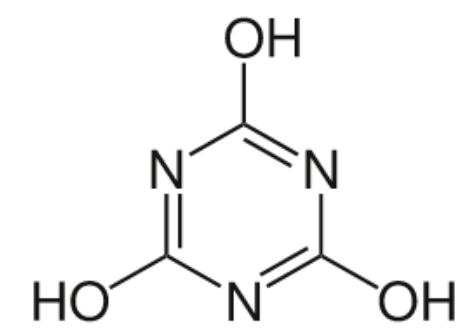

Gambar 2. Struktur kimia asam sianurat (Bizzari and Yokose, 2008)

Asam sianurat pertama kali disintesis oleh Friedrich Wöhler pada tahun 1829 melalui dekomposisi panas dari urea dan asam urat. Asam sianurat juga dapat diperoleh dengan cara hidrolisis bahan mentah atau limbah melamin yang diikuti dengan proses kristalisasi (Schaber et al., 1999). Berbagai hasil penelitian menunjukkan bahwa melamin maupun asam sianurat jika diberikan terpisah dengan dosis yang rendah relatif tidak bersifat toksik, namun demikian, berdasarkan penelitian terhadap hewan uji diketahui bahwa kombinasi melamin dan asam sianurat dapat menyebabkan gangguan ginjal (WHO, 2008).

\section{Melamin sianurat}

Melamin sianurat atau disebut juga kompleks asam melamin-sianurat dengan rumus formula kimia $\mathrm{C}_{6} \mathrm{H}_{9} \mathrm{~N}_{9} \mathrm{O}_{3}$ dan nama IUPAC 1,3,5-triazinane-2,4,6-
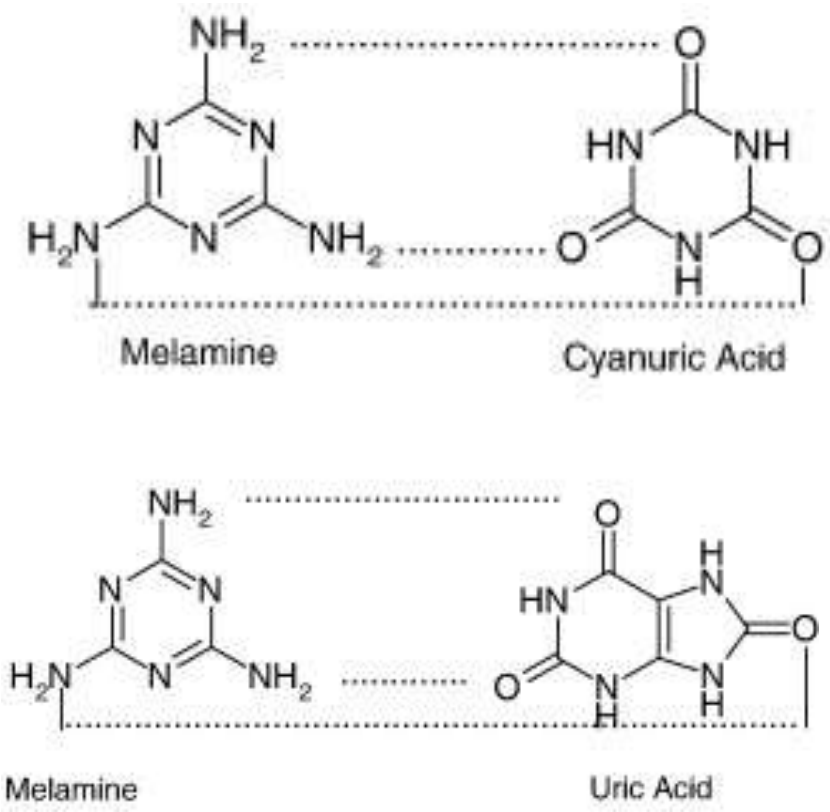

Gambar 3. Struktur kimia melamin sianurat (Bizzari and Yokose, 2008)

trione;1,3,5-triazine-2,4,6-triamine adalah kompleks kristal yang terbentuk dari campuran melamin dan sianurat dengan perbandingan 1:1 (He et al., 2008).

Kompleks melamin sianurat sangatlah baik digunakan sebagai material penahan panas karena stabil terhadap perubahan temperatur (Qiu and Gao, 2005). Puschner and Reimschuessel (2011) menyatakan bahwa kombinasi melamin dan asam sianurat (melamin sianurat) jauh lebih toksik dibandingkan dengan melamin atau asam sianurat. Selanjutnya, melamin sianurat membentuk kristal tidak larut yang sangat berbahaya karena dapat merusak tubulus ginjal (Suchý et al., 2009) dan saat ini telah ditemukan juga sebagai pencemar dalam pakan ruminansia yang berbasis urea (EFSA, 2010).

\section{Penyalahgunaan Melamin}

Melamin pada sekitar tahun 1958 telah dimanfaatkan sebagai tambahan pada pakan ternak karena mengandung $\mathrm{N}$ dalam jumlah yang besar (66\%). Namun penggunaan tersebut dihentikan pada tahun 1978 karena melamin tidak dapat dihidrolisa secara sempurna dalam rumen (Newton and Utley, 1978). Selanjutnya telah dilaporkan kejadian pencemaran melamin yang terdapat pada bahan makanan dan pakan asal produk nabati atau hewani di sejumlah negara seperti Taiwan, Singapura, danVietnam (Ingelfinger, 2008). Hasil penelusuran kejadian menunjukkan bahwa sedikitnya 6 anak meninggal di China karena 
gagal ginjal parah yang diduga akibat melamin serta turunannya seperti asam sianurat yang ditambahkan ke dalam susu bubuk dan lebih dari 200.000 bayi serta anak kecil mengalami gangguan ginjal dengan lebih dari 50.000 bayi dan anak kecil dirawat di rumah sakit (Ingelfinger, 2008). Lebih parah lagi, bahan-bahan atau produk susu formula yang terkontaminasi tersebut oleh China juga diekspor ke negara negara seperti Hong Kong, Macau, Taiwan, Singapura, Jepang, Korea Selatan, dan Australia sehingga menimbulkan masalah yang sama (Lam et al., 2008; Wang et al., 2009). Tahun 2007, produk pakan hewan ditarik dari peredaran di Amerika Utara oleh beberapa produsen pakan hewan kesayangan setelah ditemukan sejumlah kasus kucing dan anjing yang sakit dan mati akibat mengonsumsi pakan terkontaminasi melamin dan turunannya seperti asam sianurat (Puschner et al., 2007). Food and Drug Administration (FDA) melaporkan melamin dan turunannya seperti asam sianurat telah terdeteksi dalam bahan pakan untuk kucing dan anjing dalam pakan hewan dan sampel gluten gandum yang diimpor dari di China (Brown et al,. 2007). Selain ditemukan pada produk susu formula bayi dan bahan pakan anjing serta kucing, melamin dan turunannya juga ditemukan pada pakan anak babi (Gonzalez et al., 2009), konsentrat sapi perah (Cruywagen, et al., 2009), pakan ikan (Yan et al., 2009) dan pakan unggas (Straková et al., 2014).

Menurut Hau et al. (2009), ditemukannya asam sianurat dalam bahan pakan kemungkinan merupakan unsur kesengajaan atau merupakan produk samping dari melamin dalam bahan pakan tersebut. Senyawa tersebut terdeteksi dalam gluten gandum, jagung dan protein beras dengan konsentrasi $0.8 \%$ sampai $26 \%$ (Brown et al., 2007). Dipandang dari sisi ekonomi, strategi untuk melakukan kecurangan dengan cara menambah melamin yang memiliki kandungan nitrogen tinggi $(66,6 \%)$ pada bahan pakan untuk meningkatkan keuntungan menjadi sebuah pilihan yang cukup menarik bagi kalangan industri. Hal tersebut dapat terjadi karena sampai saat ini untuk mengukur konsentrasi protein yang terdapat dalam bahan pakan tersebut adalah dengan menggunakan metode Kjeldahl (Krotz et al., 2008). Meskipun pada akhirnya pilihan strategi tersebut menimbulkan dampak negatif yang luas dan berkepanjangan.

Guna meminimalisir kejadian tersebut maka diperlukan suatu metode kuantitatif yang terpercaya untuk menentukan kandungan total protein sejati yang terdapat dalam bahan pakan sehingga ada jaminan kepastian kualitas dan keamanannya (Moore et al., 2010). Abbas et al. (2013) dalam penelitiannya menggunakan metode spektroskopi near infrared (NIR) untuk deteksi melamin dan turunannya seperti asam sianurat dalam sampel pakan seperti bungkil kedelai, gluten jagung dan gluten gandum. Metode analisis modern lain yang dapat digunakan untuk menentukan kandungan melamin, asam sianurat dan melamin sianurat adalah dengan menggunakan metode High Performance Liquid Chromatography (HPLC), Liquid Chromatography-Ultraviolet (LCUV), Liquid Chromatography Mass Spectrophotometry (LC-MS), High Performance Liquid Chromatography diode array detection (HPLC-DAD), liquid chromatograph coupled with mass detector (LC/MS/ MS), liquid chromatography with triple quadrupole tandem mass spectrometry (UPLC/MS/MS) dan Matrix-assisted laser desorption/ionization-mass spectrometry (MALDI-MS), molecular imprinting and solid-phase extraction (MI-SPE) (Yokley et al., 2000; Vail et al., 2007; Fremlin and Pelzing, 2009; Yang et al., 2009; Yu et al., 2010; Filazi et al., 2012). Metode yang dapat digunakan untuk menentukan kandungan melamin, asam sianurat dan melamin sianurat dalam bahan pakan terangkum pada Tabel 1 .

Namun demikian metode tersebut tampaknya masih sulit dilakukan di laboratorium sederhana karena terkendala mahalnya harga alat dan kemampuan

Tabel 1. Metode penentuan kandungan melamin, asam sianurat dan melamin sianurat dalam bahan pakan

\begin{tabular}{|c|c|c|}
\hline Sampel uji & Metode & Referensi \\
\hline Tanah & LC-UV & $\begin{array}{l}\text { Yokley et al., } \\
2000\end{array}$ \\
\hline $\begin{array}{l}\text { Trout, tilapia, salmon, } \\
\text { dan udang }\end{array}$ & LC-MS/MS & $\begin{array}{l}\text { Andersen } \text { et al., } \\
2008\end{array}$ \\
\hline $\begin{array}{l}\text { Gluten, pakan ayam } \\
\text { komersial }\end{array}$ & $\begin{array}{l}\text { Raman spectros- } \\
\text { copy dan HPLC }\end{array}$ & Lin et al., 2008 \\
\hline Dog food kering & ELISA & Garber, 2008 \\
\hline Protein nabati & $\mathrm{LC} / \mathrm{MS} / \mathrm{MS}$ & Ding et al., 2008 \\
\hline $\begin{array}{l}\text { Daging babi dan sereal } \\
\text { gandum }\end{array}$ & HPLC & Wei et al., 2009 \\
\hline $\begin{array}{l}\text { Susu dan produk asal } \\
\text { susu }\end{array}$ & GC-MS/MS & Miao et al., 2009 \\
\hline Susu bubuk & MI-SPE & Yang et al., 2009 \\
\hline $\begin{array}{l}\text { Beras dan konsentrat } \\
\text { kacang }\end{array}$ & $\mathrm{LC} / \mathrm{MS} / \mathrm{MS}$ & Suchý et al., 2009 \\
\hline Suplemen protein & HPLC-DAD & $\begin{array}{l}\text { Montesano et al., } \\
2013\end{array}$ \\
\hline Susu formula bayi & UPLC/MS/MS & Meng et al., 2015 \\
\hline
\end{tabular}


sumber daya manusia yang masih terbatas dalam pengoperasian alat alat tersebut. Mahalnya metode canggih yang dapat digunakan untuk deteksi tersebut secara langsung maupun tidak langsung akan memicu pemalsuan protein dengan penambahan melamin dalam bahan pakan maupun makanan untuk memperoleh keuntungan yang lebih besar.

\section{Absorpsi, Distribusi, Metabolisme dan Ekskresi}

Melamin dan asam sianurat pada hewan secara cepat diabsorpsi dan diekskresikan serta hampir seluruhnya tidak berubah dalam urin. Waktu paruh eliminasi untuk senyawa melamin dan asam sianurat sekitar 2,7 - 4,04 jam (Mast et al., 1983). Lebih dari 90\% melamin yang terkonsumsi diekskresikan dalam waktu 24 jam (Hau et al., 2009). Liu et al. (2010) menunjukkan bahwa melamin dosis tunggal $1,4 \mathrm{mg} /$ kgBB pada monyet rhesus secara oral akan diabsorbsi dengan cepat dan diekskresikan terutama melalui urin. Penelitian pada babi menunjukkan bahwa pemberian melamin secara IV dengan dosis $6,13 \mathrm{mg} / \mathrm{kg}$ memiliki waktu paruh 4,04 $\pm 0,37 \mathrm{jam}$, klirens $0,11 \pm 0,011 / \mathrm{jam} /$ $\mathrm{kg}$ dan volume distribusi 0,61 $\pm 0,041 / \mathrm{kg}$ (Baynes et al., 2008). Penelitian oleh Mast et al., (1983) menggunakan tikus jantan galur Fischer 344 menunjukkan bahwa melamin dengan cepat diserap setelah pemberian oral serta tidak mengalami perubahan setelah diekskresikan ke dalam urin. Penelitian tersebut juga menunjukkan bahwa kadar melamin ditemukan dalam jumlah yang sama pada darah, hepar dan plasma. Hau et al. (2009) menyatakan bahwa melamin tidak dimetabolisme pada hewan dan $90 \%$ diantaranya diekskresikan melalui ginjal selama 24 jam setelah terkonsumsi. Sejalan dengan hasil penelitian tersebut, Thompson et al. (2008) juga menyatakan bahwa melamin dan senyawa turunannya tidak terakumulasi dalam tubuh tetapi dengan cepat akan dieliminasi oleh ginjal. Namun sebaliknya, Straková et al. (2014) menyatakan bahwa melamin dan/atau turunannya dapat tersimpan dalam tubuh manusia atau hewan, sehingga jika mengonsumsi makanan atau pakan yang mengandung komponen tersebut akan berdampak pada kesehatan. Lebih lanjut, Zheng et al. (2013) menunjukkan bahwa biotransformasi melamin pada tikus diperantarai oleh mikroorganisme Klebsiella terrigena yang terdapat dalam saluran pencernaan. Bakteri tersebut mampu merubah melamin menjadi asam sianurat yang kemudian diduga dapat menjadi komponen utama kalkuli ginjal. Hasil penelitian yang sangat beragam tersebut diatas menunjukkan bahwa masih diperlukan penelitian yang lebih mendalam terhadap absorpsi, distribusi, metabolisme dan ekskresi melamin dan senyawa turunannya pada bermacam spesies hewan (Dorne et al., 2013). Hasil penelitian pada anjing yang menarik ditunjukkan oleh Barbee et al. (1984) dan Hammond et al. (1985) dimana dosis $5 \mathrm{mg} / \mathrm{kgBB}$ asam sianurat yang diberikan baik per oral maupun intravena seluruhnya akan terabsorbsi, sedangkan sediaan bolus dengan dosis $500 \mathrm{mg} / \mathrm{kg}$ BB hanya sebagian yang terserap. Penelitian tersebut juga menunjukkan bahwa volume yang terdistribusi sangatlah sedikit jika dibandingkan dengan volume cairan tubuh, yaitu $0,7 \mathrm{l} /$ $\mathrm{kg}$, sedangkan waktu paruh menunjukkan 1,5-2 jam dan dengan mudah asam sianurat dapat dieliminasi melalui ginjal. Hasil penelitian tersebut tidak menunjukkan adanya bioakumulasi dalam jaringan dan tidak ada metabolit selain asam sianurat yang terdeteksi dalam hasil ekskresi.

Shen et al. (2010) menyatakan bahwa melamin dapat diekskresikan oleh sapi perah ke dalam susu, terutama pada sapi perah dengan produksi tinggi, meskipun tidak berpengaruh pada komposisinya. Lebih lanjut, Lutter et al., (2011) dalam laporannya menyebutkan bahwa pada pakan ternak yang mengandung melamin $15 \mathrm{ppm}$ (15000 ppb), setelah 5 jam di absorpsi ternak, ternyata susunya mengandung melamin dengan konsentrasi $2 \%$ dari total melamin pada pakan (300 ppb). Cruywagen et al. (2009) menambahkan bahwa susu akan mengandung melamin jika sapi digembalakan di padang rumput yang dipupuk dengan melamin. Dalam waktu 8 jam, melamin akan ditransfer ke susu dan jaringan tubuh dengan efisiensi 2,1\% - 3\%. Laporan kasus oleh Reyers (2008) menyatakan bahwa melamin diekskresikan ke dalam susu sapi yang mengonsumsi konsentrat protein tinggi. Lebih lanjut dinyatakan dalam laporan tersebut bahwa konsentrat protein tinggi tersebut terkontaminasi oleh melamin.

Hasil penelitian penelitian tersebut menunjukkan masih diperlukannya penelitian yang mendalam terhadap berbagai spesies hewan yang mengonsumsi pakan dengan bahan bahan pakan berbasis impor. Lembaga-lembaga yang berkompeten diharapkan dapat melengkapi laboratorium yang dimilikinya untuk dapat mendeteksi adanya melamin dalam produk pakan komersial maupun bahan pakan yang diimpor. Laboratorium yang ada sebaiknya dilengkapi dengan salah satu atau beberapa alat metode deteksi seperti High 
Performance Liquid Chromatography (HPLC), Liquid Chromatography-Ultraviolet (LC-UV), Liquid Chromatography Mass Spectrophotometry (LC-MS), High Performance Liquid Chromatography diode array detection (HPLC-DAD), liquid chromatograph coupled with mass detector (LC/MS/MS), liquid chromatography with triple quadrupole tandem mass spectrometry (UPLC/MS/MS), dan Matrix-assisted laser desorption/ionization-mass spectrometry (MALDI-MS), molecular imprinting and solid-phase extraction (MI-SPE). Penggunaan metode tersebut diharapkan dapat mencegah munculnya kejadian penyakit saluran perkencingan pada hewan kesayangan seperti kucing dan anjing yang diakibatkan oleh pakan.

\section{Toksisitas}

Melamin pada dasarnya memiliki batas keamanan yang lebar sehingga relatif tidak beracun jika terkonsumsi manusia dan hewan (Cocchi et al., 2010). Namun sebaliknya, menurut Weise (2007) melamin berbahaya jika tertelan, terhirup, atau terserap kulit. Paparan secara kronik dapat memicu terjadinya kanker dan kerusakan sistem reproduksi dan dosis toksik dari melamin cukup tinggi dengan LD50 3,161 mg per kg berat badan (WHO, 2008; Hau et al., 2009).

Data toksisitas melamin masih terbatas, namun hasil pengujian pada hewan menunjukkan bahwa melamin dapat menyebabkan terbentuknya batu pada vesika urinaria. Data toksisitas melamin, asam sianurat dan melamin sianurat yang berasal dari penelitian penelitian yang lain tersaji dalam Tabel 2. Efek toksik utama pada tikus dan mencit yang terpapar melamin melalui pakannya antara lain terbentuknya batu, reaksi keradangan, dan hiperplasia pada kandung kemih (ElRabey et al., 2013). Pengujian pada anjing diperoleh hasil terbentuknya kristaluria melamin, sedangkan pada tikus ditemukan terjadinya hematuria. Penelitian oleh Puschner et al. (2007) menunjukan toksisitas melamin dan asam sianurat pada paparan oral tunggal dengan konsentrasi $32 \mathrm{mg} / \mathrm{kg}$ dari masing-masing senyawa dapat mengakibatkan gagal ginjal akut pada kucing. Kasus gagal ginjal pada 2 ekor anjing akibat pakan yang terkontaminasi melamin telah dilaporkan oleh Cocchi et al. (2010). Laporan tersebut menyatakan bahwa melamin dengan kadar 766,8 ppm dan 158,5 ppm telah terdeteksi pada pakan yang diberikan. Beberapa uji paparan oral subkronik asam sianurat menunjukkan bahwa senyawa tersebut dapat menyebabkan kerusakan jaringan ginjal terhadap hewan uji, termasuk dilatasi tubulus renalis (Xie et al., 2010), nekrosis atau hiperplasia epitelium tubular (El-Rabey, et al., 2013) peningkatan tubulus basofilik, infiltrasi neutrofilik, mineralisasi dan fibrosis (Nilubol et al., 2009). Kondisi tersebut di atas kemungkinan disebabkan oleh adanya kristal sianurat dalam tubulus renalis (Thompson et al., 2008; Skinner et al., 2010). Melamin dan asam sianurat memiliki toksisitas rendah bila diberikan secara terpisah, namun demikian mereka mampu menginduksi terbentuknya kristal pada ginjal saat diberikan secara bersamaan. Selanjutnya jika terjadi gagal ginjal maka kemungkinan akan serupa dengan nefropati asam urat akut pada manusia, di mana kristal sferulit akan mengakibatkan obstruksi pada tubulus ginjal (Reimschuessel et al., 2008).

\section{Gejala Klinis}

Gejala klinis yang muncul dapat bervariasi sehingga sulit menentukan secara pasti tanpa bantuan pemeriksaan laboratorium atau bahkan histopatologi. Gejala klinis paparan oral dosis tunggal melamin dan

Tabel 2. Toksisitas melamin, asam sianurat, melamin-sianurat.

\begin{tabular}{|c|c|c|c|c|}
\hline Hewan & Kandungan & Dosis & Dampak & Referensi \\
\hline Anjing & Melamin & $125 \mathrm{mg} / \mathrm{kg} \mathrm{BB}$ & Diuresis & Lipschitz and Stokey, 1945 \\
\hline Domba & Melamin & $2500 \mathrm{mg} / \mathrm{kg} \mathrm{BB}$ & $\begin{array}{l}\text { BUN meningkat, stress, } \\
\text { anoreksia dan anuria }\end{array}$ & Clark, 1966 \\
\hline Tikus jantan & Melamin & $150 \mathrm{mg} / \mathrm{kgBB}$ (90 hari) & Batu di vesika urinaria & Melnick et al., 1984 \\
\hline Kucing & Melamin sianurat & $32 \mathrm{mg} / \mathrm{kg}$ & Gagal ginjal akut & Puschner et al., 2007 \\
\hline Ikan & Melamin sianurat & $\begin{array}{l}400 \mathrm{mg} \text { melamin }+400 \\
\text { asam sianurat } \mathrm{mg} / \mathrm{kg} \text { pakan }\end{array}$ & $\begin{array}{l}\text { Ginjal } \\
\text { tampak sedikit bengkak pada } \\
\text { beberapa ikan }\end{array}$ & Reimschuessel et al., 2008 \\
\hline Wistar & Melamin & $100 \mathrm{mg} / \mathrm{kg}$ & Kerusakan ginjal & Xie et al., 2010 \\
\hline Broiler & Melamin sianurat & $\begin{array}{l}\text { melamin } 100 \mathrm{mg} / \mathrm{kg} \text { pakan } \\
\text { dan asam sianurat } 100 \mathrm{mg} / \\
\text { kg pakan }\end{array}$ & $\begin{array}{l}\text { Hipoproteinemia, hipoglikemia, } \\
\text { hipokalemia, hiponatremia, } \\
\text { kerusakan hati }\end{array}$ & Straková et al., 2014 \\
\hline
\end{tabular}


asam sianurat $32 \mathrm{mg} / \mathrm{kg}$ dari masing masing senyawa berupa anoreksia, muntah dan depresi (Puschner et al., 2007). Laporan gejala klinis akibat keracunan melamin sianurat yang teramati oleh pemilik kucing meliputi penurunan nafsu makan, muntah, poliuria, polidipsia, lesu dan azotemia (Cianciolo et al., 2008). Gejala klinis yang muncul pada anjing 12 jam setelah terpapar melamin sianurat berupa kelesuan disertai muntah ataupun tanpa muntah. Keracunan melamin sianurat akan terlihat jelas setelah muncul gejala disfungsi ginjal, polidipsia, poliuria, kelemahan, kelesuan, dan dehidrasi (Puschner et al., 2007; Puschner and Reimschuessel, 2011). Hasil pengamatan gejala klinis keracunan melamin dan asam sianurat pada anak babi menunjukkan terjadinya anoreksi, depresi, lesu dan polidipsi. Gejala klinis tersebut muncul beberapa hari setelah disapih, dengan angka morbiditas 40-60\% (Gonzalez et al., 2009). Keracunan melamin dan asam sianurat pada babi juga telah dilaporkan, meskipun kematian terjadi tanpa gejala klinis yang menciri. Namun demikian, gejala klinis yang dapat teramati adalah kulit menjadi pucat, penurunan berat badan dan meningkatnya angka kematian. Pemeriksaan bedah bangkai pada babi tersebut menunjukkan terjadinya gagal ginjal (Nilubol et al., 2009).

Dari hasil hasil penelitian diatas serta rangkuman pada tabel 3 dapat diketahui bahwa gejala klinis yang muncul akibat keracunan melamin, asam sianurat atau melamin sianurat sangatlah umum sehingga sulit untuk menentukan diagnosa secara pasti. Selain gejala klinis, diagnosa secara pasti ditentukan dengan riwayat lengkap, pemeriksaan kimia darah, analisa urin, nekropsi, pemeriksaan organ dan pembuatan preparat histologi (Thompson et al., 2008; Cocchi et al., 2010).

\section{Melamin dan Gangguan Saluran Perkencingan}

Patogenesis toksisitas ginjal yang terkait dengan konsumsi melamin mungkin belum sepenuhnya dapat dijelaskan secara pasti, namun kristal tubular yang mengandung melamin telah terbukti melalui pemeriksaan rutin dengan metode formalin-fixed, paraffin-embedded dari ginjal hewan domestik (Lewin-

Tabel 3. Gejala klinis akibat melamin, asam sianurat, melamin-sianurat.

\begin{tabular}{|c|c|c|c|}
\hline Hewan & Bahan & Gejala klinis & Referensi \\
\hline Domba & Melamin dalam suplemen pakan & Penurunan berat badan & MacKenzie, 1966 \\
\hline Mencit B6C3F1 & Melamin & Penurunan berat badan & $\begin{array}{l}\text { NTP (National Toxicology } \\
\text { Programme), } 1983\end{array}$ \\
\hline Kucing & Melamin dan asam sianurat & Muntah, kelemahan umum dan anoreksi & Puschner et al., 2007 \\
\hline Anjing & Melamin dalam dog food & $\begin{array}{l}\text { Rasa sakit pada abdomen, kelemahan } \\
\text { umum, anoreksi, muntah dan depresi. }\end{array}$ & Cocchi et al., 2010 \\
\hline Babi & Melamin dalam yeast & $\begin{array}{l}\text { Anoreksia, kurus, rambut kusam, dan } \\
\text { depresi }\end{array}$ & Lee et al., 2011 \\
\hline Wistar jantan & Melamin & Penurunan berat badan, hematuria & An et al., 2011 \\
\hline
\end{tabular}

Tabel 4. Dampak mjelamin, asam sianurat atau melamin sianurat dan pada saluran perkencingan

\begin{tabular}{|c|c|c|c|}
\hline Hewan & Bahan & Perubahan & Referensi \\
\hline Domba & Melamin & Terbentuk kristaluria & Clark, 1966 \\
\hline Kucing & $\begin{array}{l}\text { Melamin dan asam sianurat dalam } \\
\text { pakan komersial }\end{array}$ & Terbentuk batu ginjal & Puschner et al., 2007 \\
\hline Ikan Salmon & Asam sianurat & $\begin{array}{l}\text { Kompleks kristal melamin-sianurat dalam } \\
\text { ginjal }\end{array}$ & Reimschuessel et al., 2008 \\
\hline Babi & Melamin sianurat & Kristal pada ginjal & Reimschuessel et al., 2008 \\
\hline Kucing & Melamin dalam pakan komersial & $\begin{array}{l}\text { Kristal mengandung melamin sianurat } \\
\text { dalam ginjal }\end{array}$ & Dobson et al., 2008 \\
\hline Anjing & Melamin dalam pakan komersial & $\begin{array}{l}\text { Deposisi kristal yang mengandung Melamin } \\
\text { dalam tubulus ginjal dan pelvis renalis. } \\
\text { Deposit urolith dalam medulla ginjal }\end{array}$ & Cocchi et al., 2010 \\
\hline Mencit & Melamin & Terbentuk batu ginjal & Peng et al., 2012 \\
\hline Tikus F344 & Melamin sianurat & Gagal ginjal akut & Kobayashi et al., 2016 \\
\hline
\end{tabular}


Smith et al., 2009). Selain menyebabkan kristaluria, melamin juga dapat menyebabkan diuresis pada tikus percobaan dan anjing (Melnick et al., 1984; Brown et al., 2007). Hasil penelitian kandungan pakan komersial yang ditarik dari peredaran juga mengandung melamin dan asam sianurat yang kemungkinan mengakibatkan terbentuknya kristal di urin dan ginjal kucing (Burns et al., 2007).

Laporan di Klinik Hewan Departemen Ilmu Penyakit Dalam, FKH-UGM juga menunjukkan banyaknya kasus kristal yang ditemukan dalam urin pada kucing. Dari anamnesa yang diperoleh, hampir semua pasien kucing tersebut diberi pakan kering komersial dengan berbagai nama dagang (Nururrozi et al., 2018). Meskipun demikian, dalam kasus kasus tersebut diatas masih diperlukan analisa lebih lanjut untuk mendeteksi adanya melamin dan/atau turunannya, baik dalam pakan maupun kristal yang terbentuk dalam urin.

Tabel 4 menunjukkan berbagai penelitian maupun laporan kasus yang melibatkan melamin, asam sianurat atau melamin sianurat dalam pembentukan batu ataupun kristal di saluran perkencingan. Dari Tabel 4 tersebut dapat terlihat bahwa melamin dan/ atau turunannya yang diberikan pada hewan percobaan ataupun yang terkandung dalam pakan komersial dapat mengakibatkan berbagai bentuk gangguan pada saluran perkencingan. Menurut Dobson et al. (2008) Melamin sianurat memiliki kelarutan yang sangat rendah dan dihipotesiskan bahwa hal tersebut akan mengarah pada pembentukan kristal melamin sianurat di dalam ginjal. Diasumsikan bahwa melamin sianurat diserap dalam saluran pencernaan, didistribusikan secara sistemik dan meskipun belum jelas, melamin sianurat akan membentuk endapan dalam tubulus ginjal selanjutnya akan menyebabkan penyumbatan tubular yang bersifat progresif serta degenerasi. Penyumbatan tersebut pada akhirnya akan mengakibatkan gagal ginjal.

\section{Kesimpulan}

Hasil penelitian menunjukkan bahwa melamin, asam sianurat dan melamin sianurat merupakan senyawa yang berbahaya karena kemampuannya mengakibatkan penyakit pada saluran perkencingan hewan kesayangan, terutama anjing dan kucing. Meskipun diperlukan peralatan yang canggih dan biaya mahal, saat ini deteksi melamin dalam bahan pakan maupun produk jadi harus dilakukan untuk menghindari terjadinya kasus penyakit saluran perken- cingan yang diakibatkannya. Penanganan kasus kasus di klinik maupun rumah sakit hewan yang terkait dengan gangguan saluran perkencingan saat ini harus mulai diarahkan salah satunya terhadap kemungkinan akibat mengonsumsi melamin yang mungkin terdapat dalam produk pakan jadi untuk anjing maupun kucing.

\section{Daftar Pustaka}

Abbas, O., Lecler, B., Dardenne, P. and Baeten, V. (2013). Detection of Melamine and Cyanuric Acid in Feed Ingredients by near Infrared Spectroscopy and Chemometrics J. Near Infrared Spectrosc. 21(3): 183-194. doi: 10.1255/jnirs.1047.

An, L., Li, Z., Yang, Z. and Zhang, T. (2011). Cognitive Deficits Induced by Melamine in Rats. Toxicol. Lett. 206 (3): 276-280. doi:10.1016/j. toxlet.2011.08.009.

Andersen, W.C., Turnipseed, S.B., Karbiwnyk, C.M., Clark, S.B., Madson, M.R. and Gieseker, C.M. (2008). Determination and Confirmation of Melamine Residues In Catfish, Trout, Tilapia, Salmon, and Shrimp by Liquid Chromatography With Tandem Mass Spectrometry. J. Agric. Food Chem. 56(12):4340-4347. doi:10.1021/ jf800295z.

Anonim. (2009). MELAMINE CAS $\mathrm{N}^{\circ}: 108-78$ 1. UNEP Publications. www.inchem.org/ documents/sids/sids/108781.pdf.

Barbee, S.J., Cascieri, T., Hammond, B.G., Inoue, T., Ishida, N., Wheeler, A.G., Chadwick, M., Hayes, D., MacCauley, M., and McComish, A. (1984). Metabolism and Disposition of Sodium Cyanurate. Toxicologist. 4: 92.

Barboza, D. and Barrionuevo A. (2007). Filler in animal feed is open secret in China. New York Times, 30 April 2007 (http://www.nytimes. com/2007/04/30/business/worldbusiness/ 30 food.html).

Baynes, R.E., Smith, G., Mason, S.E., Barrett, E., Barlow, B.M. and Riviere, J.E. (2008). Pharmacokinetics of Melamine In Pigs Following Intravenous Administration. Food Chem. Toxicol. 46(3): $1196-1200$. DOI:10.1016/j.fct.2007.11.013. 
Bizzari, S. and Yokose, K. (2008). Melamine. In: Chemicaleconomicshandbook. Menlo Park, CA, SRI Consulting, Inc. (http://www.sriconsulting. com/CEH/Public/Reports/673.3000/; diakses 16 Januari 2018).

Brown, C.A., Jeong, K.S., Poppenga, R.H., Puschner, B., Miller, D.M., Ellis, A.E., Kang, K.I., Sum, S., Cistola, A.M. and Brown S.A. (2007). Outbreaks of Renal Failure Associated With Melamine and Cyanuric Acid In Dogs and Cats in 2004 and 2007. J. Vet. Diagn. Invest. 19 (5): 525-531. DOI:10.1177/104063870701900510.

Burns, K., Nolen, S., Kahler, S., Rezendes, A. (2007). Recall of Pet Food Leaves Veterinarians Seeking Solutions. J Am Vet Med Assoc. 230 (8):11281129, 1136-1138. 10.2460/javma.230.8.1126.

Cheng, Y., Dong, Y., Wu, J., Yang, X., Bai, H., Zheng, H., Ren, D., Zou, Y. and Li, M. (2010). Screening Melamine Adulterant in Milk Powder with Laser Raman spectrometry. J. Food Compos. Anal. 23 (2): 199-202. doi.org/10.1016/j. jfca.2009.08.006.

Chuenarrom, C., Daosodsai, P. and Charoenphol, P. (2014). Effect of Excessive Trichloroisocyanuric Acid in Swimming Pool Water on Tooth Erosion. Songklanakarin J. Sci. Technol. 36 (4): 445-450.

Cianciolo, R.E., Bischoff, K., Ebel, J.G., Van Winkle, T.J., Goldstein, R.E. and Serfilippi, L. M. (2008). Clinicopathologic, Histologic, And Toxicologic Findings in 70 Cats Inadvertently Exposed to Pet Food Contaminated with Melamine and Cyanuric Acid. J. Am. Vet. Med. Assoc. 233(5): 729-737. doi: 10.2460/ javma.233.5.729.

Clark, R. (1966). Melamine Crystalluria in Sheep. JSAVA. 37 (3): 349-351.

Cocchi, M., Vascellari, M., Gallina, A., Agnoletti, F., Angeletti, R. and Mutinelli, F. (2010). Canine Nephrotoxicosis Induced by MelamineContaminated Pet Food in Italy. J. Vet. Med. Sci. 72(1): 103-107. https://doi.org/10.1292/ jvms.09-0278.

Cruywagen, C.W., Stander, M.A., Adonis, M. and Calitz, T. (2009) Hot topic: Pathway confirmed for the transmission of melamine from feed to cow's milk. J. Dairy Sci. 92 (5):2046-2050 doi:10.3168/jds.2009-2081.

Ding, T., Xu, J., Li, J., Shen, C., Wu, B., Chen, H. and Li, S. (2008). Determination of Melamine Residue in Plant Origin Protein Powders Using High Performance Liquid Chromatographydiode Array Detection and High Performance Liquid Chromatography-Electrospray Ionization Tandem Mass Spectrometry. Chin. J. Chrom. 26 (1):6-9.

Dobson, R.L., Motlagh, S., Quijano, M., Cambron, R.T, Baker, T.R., Pullen, A.M., Regg, B.T., Bigalow-Kern, A.S., Vennard, T., Fix, A., Reimschuessel, R., Overmann, G., Shan, Y. and Daston, G.P. (2008). Identification and Characterization of Toxicity Of Contaminants in Pet Food Leading to an Outbreak of Renal Toxicity in Cats and Dogs. Toxicol. Sci. 106(1):251262. doi: $10.1093 /$ toxsci/kfn160.

Dorne, J.L., Doerge, D.R., Vandenbroeck, M., FinkGremmels, J., Mennes, W., K., Knutsen, H.K., Vernazza, F., Castle, L., Edler, L. and Benford, D. (2013). Recent Advances in The Risk Assessment of Melamine and Cyanuric Acid in Animal Feed. Toxicology and Applied Pharmacology 270 (3): 218-229. https://doi. org/10.1016/j.taap.2012.01.012.

Downes, C.J., Mitchell, J.W., Viotto, E.S. and Eggers, N.J. (1984). Determination of Cyanuric Acid Levels In Swimming Pool Waters By U.V. Absorbance, HPLC And Melamine Cyanurate Precipitation. Water Research 18 (3): 277-280. doi.org/10.1016/0043-1354(84)90100-3.

EFSA. (2010). Scientific Opinion on Melamine in Food and Feed EFSA Panel on Contaminants in the Food Chain (CONTAM) and EFSA Panel on Food Contact Materials, Enzymes, Flavourings and Processing Aids (CEF) European Food Safety Authority (EFSA), Parma, Italy. EFSA Journal 2010; 8(4):1573.

El-Rabey,H.A.,Al-Sieni, A.I. and Majami,A.A.(2013). The Toxic Effect of Melamine on the Kidney of Male Rats as Revealed by Biochemical and Histopathological Investigations. Life Sci J. 10(1):2119-2130.

FDA. (2008). Melamine Pet Food Recall of 2007. https://www.fda.gov/AnimalVeterinary/.../ RecallsWithdrawals/ucm129575.htm. 
Filazi, A., Sireli, U.T., Ekici, H., Can, H.Y. and Karagoz, A. (2012). Determination of Melamine in Milk and Dairy Products by High Performance Liquid Chromatography. J. Dairy Sci. 95(2):602-608. doi:10.3168/jds.2011-4926.

Fremlin, L.J. and Pelzing, M. (2009). Melamine and cyanuric acid detection in 5 minutes using LCMS. Australia: Bruker Daltonics Division, Application note.

Garber, E.A.E. (2008). Detection of Melamine Using Commercial Enzyme-Linked Immunosorbent Assay Technology. Journal of Food Protection. 71(3): 590-594.DOI10.4315/0362028X-71.3.590.

Gonzalez, J., Puschner, B., Perez, V., Ferreras, M.C., Delgado, L., Munoz, M., Perez, C., Reyes, L.E., Velasco, J., Fernandez, V. and GarciaMarın, J.F. (2009). Nephrotoxicosis in Iberian piglets subsequent to exposure to melamine and derivatives in Spain between 2003 and 2006. $J$ Vet Diagn Invest 21 (4):558-563 https://doi. org/10.1177/104063870902100425.

Gossner, C.M.E., Schlundt, J., Embarek, P.B., Hird, S., Wong, D.L.F., Beltran, J.J.O., Keng Teoh, N. and Tritscher, A. (2009). The Melamine Incident: Implications for International Food and Feed Safety. Environ. Health Perspect.117(12): 1803-1808. doi: 10.1289/ehp.0900949.

Hammond, B.G., Barbee, S.J.,.Wheeler, A.G., and Cascieri, T. (1985). Fundamental and Applied Toxicology. 5(4): 655-664. https://doi. org/10.1016/0272-0590(85)90189-7.

Hau, A.K., Kwan, T.H., and Li, P.K. (2009). Melamine toxicity and the kidney. Journal of American Society of Nephrology. 20 (2): 245-250. doi:10.1681/ASN.2008101065.

He, L., Liu, Y., Lin, M., Awika, J., Ledoux, D.R., Li, H. And Mustapha, A. (2008). A new approach to measure melamine, cyanuric acid, and melamine cyanurate using surface enhanced Raman spectroscopy coupled with gold nanosubstrates. Sens. \& Instrumen. Food Qual. 2: 66-71. doi:10.1007/s11694-008-9038-0.

Huthmacher, K., and Most, D. (2005). Cyanuric Acid and Cyanuric Chloride. Ullmann's Encyclopedia of Industrial Chemistry. Wiley-VCH, Weinheim. doi 10.1002/14356007.a08 191.
Ingelfinger, J.R. (2008). Melamine and the Global Implications of Food Contamination. $N$ Engl. J. Med. 359:2745-2748. DOI: 10.1056/ NEJMp0808410.

International Agency for Research on Cancer [IARC]. (2010). Monograph on the Evaluation of the Carcinogenik Risk of Chemicals to Man. Geneva. WHO. IARC. Monographs Vol.73. http://monographs.iarc.fr/ ENG/Monographs/ vol73/mono73-17.pdf.

Ji, A.L., Wong, Y.L., Cai, T.J. and Liu, J. (2014). Infant formula safety concerns and consequences in China. World J Pediatr. 10 (1): 7-9. doi: 10.1007/s12519-014-0447-3.

Kobayashi, T., Okada, A., Ando, R., Tozawa, K., Kohri, K. and Yasui, T. (2016). MP58-13 The Mechanism Of Renal Stone Formation And Renal Failure Induced By Melamine And Cyanuric Acid; Longterm Experiment Results. The Journal Of Urology. 195 (4): Supplement, e781. DOI: https://doi. org/10.1016/j.juro.2016.02.811.

Krotz, L., Cicerci, E. and Giazzi, G. (2008). Protein Determination in Cereals and Seeds. Food Quality 15(4):37-39.

Kumar, A., and Katiyar, V. (1990). Modelling and Experimental Investigation of Melamine Formaldehyde Polymerization. Macromolecules 23 (16): 3729-3736. DOI: 10.1021/ ma00218a003.

Lam, H.S., Ng, P.C., Chu, W.C., Wong, W., Chan, D.F., Ho, S.S., Wong, K.T., Ahuja, A.T. and Li, C.K. (2008). Renal Screening In Children After Exposure To Low Dose Melamine In Hong Kong: Cross Sectional Study. BMJ.; 337:a2991. doi.org/10.1136/bmj.a2991.

Lee, C.H., Ooi, P.T., Sheikh Omar, A.R. and Lim, B.K. (2011). Melamine Toxicity in Pigs. Pertanika J. Trop. Agric. Sci. 34 (1): 175-179.

Lewin-Smith, M.R., Kalasinsky, V.F., Mullick, F.G., Thompson, M.E. (2009). Letters to the Editor : Melamine-Containing Crystals in the Urinary Tracts of Domestic Animals: Sentinel Event?. Arch Pathol Lab Med. 133 (3): 341-342. DOI:10.1043/1543-2165-133.3.341.

Lin, M., He, L., Awika, J., Yang, L., Ledoux, D. R., Li, H. and Mustapha, A. (2008). Detection of 
Melamine In Gluten, Chicken Feed And Processed Foods Using Surface Enhanced Raman Spectroscopy and HPLC. Journal of Food Science. 73(8): T129-T134.DOI:10.1111/ j.1750-3841.2008.00901.x.

Lipschitz, W.L. and Stokey, E. (1945). The Mode of Action OfThree New Diuretics: Melamine, Adenine And Formoguanamine. Journal of Pharmacology and Experimental Therapeutics. 83 (4) 235249.

Liu, Y., Deng, J., An, L., Liang, J., Chen, F. and Wang, H. (2011). Spectrophotometric Determination Of Melamine In Milk By Rank Annihilation Factor Analysis Based On Ph Gradual ChangeUV Spectral Data. Food Chemistry. 126(2): 745750. doi.org/10.1016/j.foodchem.2010.11.057.

Liu, G., Li, S., Jia, J., Yu, C., He, J., Yu, C. and Zhu. J. (2010). Pharmacokinetic Study of Melamine In Rhesus Monkey After a Single Oral Administration of A Tolerable Daily Intake Dose. Regulatory Toxicology and Pharmacology. 56 (2):193-196. doi:10.1016/j. yrtph.2009.09.014.

Liu, Y., Todd, E.D., Zhang, Q., Shi, J.R. and Liu, X.J. (2012). Recent Developments In The Detection Of Melamine. J Zhejiang Univ Sci B 13(7): 525-532. J Zhejiang Univ Sci B. 13(7): 525532. doi: 10.1631/jzus.B1100389.

Lutter, P., Perroud, M.C.S., Gimenez, E.C., Meyer, L., Goldmann, T., Bertholet, M.C., Mottier, P., Desmarchelier, A., Florence, M., Perrin, C., Robert, F. and Delatour, T. (2011). Screening and Confirmatory Methods For The Determination of Melamine In Cow's Milk And Milk-Based Powdered Infant Formula: Validation And Proficiency-Test of ELISA, HPLC-UV, GC-MS and LC-MS/MS. Food Control. 22(6) :903-913. https://doi.org/10.1016/j.foodcont.2010.11.022.

MacKenzie, H.I. (1966). Melamine for sheep. J. S. Afr. Vet. Med. Ass. 37(2): 153-157.

Mast, R.W., Jeffcoat, A.R., Sadler, B.M., Kraska, R.C. and Friedman, M.A. (1983). Metabolism, disposition and excretion of [14C]melamine in male Fischer 344 rats. Food Chem Toxicol 21(6): 807-810. DOI10.1016/0278-6915(83)90216-8.

Maxwell, G.R. (2007). Synthetic Nitrogen Products. In: Kent and Riegel's handbook of industrial chemistry and biotechnology, 11th ed. New York, NY, Springer, pp. 996-1085.

Melnick, R.L., Boorman, G.A., Haseman, J.K., Montali, R.J. and Huff, J. (1984). Urolithiasis and Bladder Carcinogenicity Of Melamine In Rodents. Toxicol Appl Pharmacol. 72 (2): 292-303. https://doi.org/10.1016/0041008X(84)90314-4.

Meng, Z., Shi, Z.H., Liang, S.X., Dong, X.F., Lu, Y.K. and Sun, H.W. (2015). Rapid Screening and Quantification of Cyromazine, Melamine, Ammelide, Ammeline, Cyanuric Acid, And Dicyandiamide In Infant Formula By UltraPerformance Liquid Chromatography Coupled With Quadrupole Time-Of-Flight Mass Spectrometry And Triple Quadrupole Mass Spectrometry. Food Control. 55:158-65. https:// doi.org/10.1016/j.foodcont.2015.02.034.

Miao, H., Fan, S., Wu, Y.N., Zhang, L., Zhou, P.P., Li, J.G., Chen, H.J. and Zhao, Y.F. (2009). Simultaneous Determination Of Melamine, Ammelide, Ammeline, And Cyanuric Acid In Milk And Milk Products By Gas Chromatography-Tandem Mass Spectrometry. Biomed Environ Sci. 22(2):87-94. doi: 10.1016/ S0895-3988(09)60027-1.

Montesano, D., Gennari, O., Festa, C., Zollo, F., Seccia, S. and Albrizio, S. (2013). A Simple HPLCDAD Method for the Analysis of Melamine in Protein Supplements: Validation Using the Accuracy Profiles. Journal of Chemistry. 2013: 1-7,.doi.org/10.1155/2013/239342.

Moore, J.C., DeVries, J.W., Lipp, M., Griffiths, J.C. and Abernethy, D.R. (2010). Total Protein Methods and Their Potential Utility to Reduce the Risk of Food Protein Adulteration. Comprehensive Reviews in Food Science and Food Safety 9 (4): 330-357. doi 10.1111/j.15414337.2010.00114.x.

Newton, G. L. and Utley, P.R. (1978). Melamine As A Dietary Nitrogen Source For Ruminants. J. Anim. Sci. 47 (6): 1338-1344. https://doi. org/10.2527/jas1978.4761338x.

Nilubol, D., Pattanaseth, T., Boonsri, K., Pirarat, N. and Leepipatpiboon, N. (2009). Melamine- and Cyanuric Acid-Associated Renal Failure in Pigs in Thailand. Vet Pathol 46 (6):1156-1159 (2009) DOI: 10.1354/vp.08-VP-0233-N-FL. 
NTP (National Toxicology Programme). (1983). Carcinogenesis bioassay of melamine (CAS No. 108- 78-1) in $\mathrm{F} 344 / \mathrm{N}$ rats and $\mathrm{B} 6 \mathrm{C} 3 \mathrm{~F} 1$ mice (feed study). Research Triangle Park, NC, and Bethesda, MD, United States Department of Health and Human Services, Public Health Service, National Institutes of Health, National Toxicology Program (NTP Technical Report Series No. 245; NTP- 81-86; NIH Publication No. 83-2501; Available from http://ntp.niehs. nih.gov/ntp/htdocs/LT_rpts/tr245.pdf). National Toxicology Program technical Report Series. 245, 1-171.

Nururrozi, A., Indarjulianto, S., Yanuartono, and Widyarini, S. (2018). Potensi Urine Acidifier untuk Mencegah Struvite Activity Prodcut (SAP) pada Kasus Feline Lower Urinary Tract Disease (A case report). Journal Veteriner (submitted).

Park, B.D. and Jeong, H.W. (2010). Cure kinetics of melamine-formaldehyde resin/clay/ cellulose nanocomposites. J. Ind. Eng. Chem. 16 (3): 375-379. https://doi.org/10.1016/j. jiec.2010.01.035.

Peng, J. , Li, D., Chan, Y.K., Chen, Y.,. Lamb, J.R., Tam, P.K. and El-Nezami, H. (2012). Effects of water uptake on melamine renal stone formation in mice. Nephrol Dial Transplant. 27 (6): 22252231 doi: 10.1093/ndt/gfr577.

Puschner, B., Poppenga, R.H., Lowenstine, L.J., Filignezi, M.S. and Pesavento, P.A. (2007). Assessment of melamine and cyanuric acid toxicity in cats. Journal of Veterinary Diagnostic Investigation. 19(6): 616-624. DOI:10.1177/104063870701900602.

Puschner, B. and Reimschuessel, R. (2011). Toxicosis Caused by Melamine and Cyanuric Acid In Dogs and Cats: Uncovering The Mystery and Subsequent Global Implications. Clin Lab Med. 31(1): 181-199. doi: 10.1016/j.cll.2010.10.003.

Qiu, Y. and Gao, L. (2005). Blue-emitting cyanuric acid-melamine complexes from urea thermolysis. Materials Research Bulletin. 40 (5): 794-799. https://doi.org/10.1016/j. materresbull.2005.02.003.

Reimschuessel, R., Evans, E.R., Stine, C.B., Hasbrouck, N., Mayer, T.D., Nochetto, C. and
Gieseker, C.M. (2010). Renal crystal formation after combined or sequential oral administration of melamine and cyanuric acid. Food Chem. Toxicol. 48 (10): 2898-2906. doi: 10.1016/j. fct.2010.07.024 .

Reimschuessel, R., Gieseker, C.M., Miller, R.A., Ward, J., Boehmer, J., Rummel, N., Heller, D.N., Nochetto, C., Turnipseed, S.B., Karbiwnyk, C.M., Satzger, R.D., Crowe, J.B., Wilber, N.R., Reinhard, M.K., Roberts, J.F. and Witkowski, M.R. (2008). Evaluation of the Renal Effects of Experimental Feeding of Melamine and Cyanuric Acid to Fish and Pigs. Am J Vet Res. 69 (9):1217-1228. https://doi.org/10.2460/ ajvr.69.9.1217

Reyers, F. (2008). Melamine is back. In milk and in South Africa. A veterinary perspective. Veterinary News, December issue.

Schaber, P.M., Colson, J., Higgins, S., Dietz, E., Thielen, D., Anspach, B. and Brauer, J. (1999). Study of the Thermal Decomposition of Urea (Pyrolysis) Reaction and Importance to Cyanuric Acid Production. American Laboratory. 31(16): 1321.

She, D.M., Yu, H.L., Huang, Q.L., Li, F.M. and Li, C.J. (2010). Liquid-Phase Synthesis of Cyanuric Acid from Urea. Molecules, 15 (3): 1898-1902; doi:10.3390/molecules15031898.

Shen, J.S., Wang, J.Q., Wei, H.Y., Bu, D.P., Sun, P. And Zhou, L.Y. (2010). Transfer Efficiency of Melamine From Feed to Milk In Lactating Dairy Cows Fed With Different Doses Of Melamine. J Dairy Sci. 93 (5) :2060-2066. DOI:10.3168/ jds.2009-2590.

Skinner, C.G., Thomas, J.D. and Osterloh, J.D. (2010). Melamine Toxicity. J. Med. Toxicol. 6(1):50-55 DOI 10.1007/s13181-010-0038-1.

Straková, E., Karásková, K., Zapletal, D. and Suchý, P. (2014). Effect of Melamine And Cyanurid Acid Contaminated Diets On Blood Indicators In Broiler Chickens. Czech J. Anim. Sci. 59 (12): 564-570.

Suchý, P., Straková, E., Herzig, I., Staňa, J., Kalusová,R. and Pospíchalová, M. (2009). Toxicological Risk Of Melamine And Cyanuric Acid In Food And Feed. Interdiscip Toxicol. 2(2): 55-59. doi: 10.2478/v10102-009-0010-6. 
Sugita, T., Ishiwata, H. and Yoshihira, K. (1990). Release of Formaldehyde and Melamine From Tableware Made of Melamine-Formaldehyde Resin. Food Addit. Contam. 7(1):21-27. DOI:10.1080/02652039009373815.

Thompson, M. E., Lewin-Smith, M. R., kalasinsky, V. F. Pizzolato, K. M., Fleetwood, M. L., Mcelhaney, M. R. and Johnson, T. O. (2008). Characterization of Melamine-containing and Calcium Oxalate Crystals in Three Dogs with Suspected Pet Food-induced Nephrotoxicosis. Vet Pathol. 45(3):417-426. DOI:10.1354/vp.453-417.

Vail, T., Jones, P.R. and Sparkman, O.D. (2007). Rapid and Unambiguous Identifi Cation of Melamine in Contaminated Pet Food Based on Mass Spectrometry with Four Degrees Of Confirmation. J Anal Toxicol. 31(6): 304-312. DOI10.1093/jat/31.6.304.

Wang, I.J., Wu, Y.N., Wu, W.C., Leonardi, G., Sung, Y.J., Lin, T.J., Wang, C.L., Kuo, C.F., Wu, K.Y., Cheng, W.C., Chan, C.C., Chen, P.C. and Lin, S.L. (2009). The Association of Clinical Findings and Exposure Profiles with Melamine Associated Nephrolithiasis. Arch Dis Child. 94(11):883-887. DOI:10.1136/ adc.2009.163477.

Wei, R., Wang, R., Zeng, Q., Chen, M. and Liu, T. (2009). High-Performance Liquid Chromatographic Method for the Determination of Cyromazine and Melamine Residues in Milk and Pork. Journal of Chromatographic Science. 47 (7) :581-584.DOI10.1093/chromsci/47.7.581.

Weise, E. (2007). Poison Pet Food Woes Seem To Hit Cats Harder. USA Today. http://www.usatoday. com/tech/science/2007-05-07-poison-petfoodscience_N.htm. Retrieved 2008-10-01.

Whitten, M.C. and Lin, C.T. (1999). Coating Performance of Polyester-Melamine Enamels Catalyzed by an in Situ Phosphatizing Reagent on AluminumInd. Eng. Chem. Res. 38 (10): 3903-3910. DOI: 10.1021/ie990231i.

WHO. (2008). Melamine and Cyanuric acid: Toxicity, Preliminary Risk Assessment and Guidance on Levels in Food 25 September 2008. - Updated 30 October 2008. www.who.int/foodsafety/fs management/Melamine.pdf.
Xie, G., Zheng, X., Qi, X., Cao, Y., Chi, Y., Su, M., Ni, Y., Qiu, Y., Liu, Y., Li, H., Zhao, A. and Jia, W. (2010). Metabonomic Evaluation of MelamineInduced Acute Renal Toxicity in Rats. $J$. Proteome Res. 9 (1):125-133 DOI: 10.1021/ pr900333h.

Yan, N., Zhou, L., Zhu, Z. and Chen, X. (2009). Determination of Melamine in Dairy Products, Fish Feed, and Fish by Capillary Zone Electrophoresis with Diode Array Detection. J. Agric. Food Chem. 57 (3): 807-811. DOI: $10.1021 / \mathrm{jf} 803429 \mathrm{e}$.

Yang, H.H., Zhou, W.H., Guo, X.C., Chen, F.R., Zhao, H.Q., Lin, L.M. and Wang, X.R. (2009). Molecularly Imprinted Polymer as SPE Sorbent for Selective Extraction of Melamine in Dairy Products. Talanta. 80(2):821-825. doi: 10.1016/j.talanta.2009.07.067.

Yokley, R.A., Mayer, L.C., Rezaaiyan, R., Manuli, M.E. and Cheung, M.W. (2000). Analytical Method for The Determination of Cyromazine and Melamine Residues In Soil Using LC-UV and GC-MSD. J Agric Food Chem. 48(8):33528. DOI: $10.1021 / \mathrm{jf} 991231 \mathrm{w}$.

Yu, H., Tao, Y., Chen, D., Wang, Y., Liu, Z., Pan, Y., Huang, L., Peng, D., Dai, M., Liu, Z. and Yuan, Z. (2010). Development of High Performance Liquid Chromatography Method and Liquid Chromatography-Tandem Mass Spectrometry Method With Pressurized Liquid Extraction for Simultaneus Quantification and Confirmation of Cyromazine, Melamine and Its Metabolites In Foods of Animal Origin. Anal Chim Acta. 682 (1-2): 48-58. DOI:10.1016/j.aca.2010.09.032.

Zheng, X., Zhao, A., Xie, G., Chi, Y., Zhao, L., Li, H., Wang, C., Bao, Y., Jia, W., Luther, M., Su, M., Nicholson, J.K. and Jia, W. (2013). Melamine-Induced Renal Toxicity is Mediated by The Gut Microbiota. Sci Transl Med. 5(172):1-5 doi: 10.1126/scitranslmed.3005114. 